ISLLAC

Journal of Intensive Studies on Language, Literature, Art, and Culture

Vol. 1 No. 1 September 2017

\title{
PROBLEMATIC SCHOOL THEATER: INTERPRETING AESTHETICS
} AND PEDAGOGY

\author{
Indra Suherjanto \\ (S3 Graduate Student ISI Yogyakarta 2015 - Lecturer Drama Department of \\ Indonesian Literature State University of Malang) \\ E-mail : indrasuherjanto@yahoo.com
}

\begin{abstract}
The phenomenon of school theater if classified includes the following issues: 1) the resources of teachers and coaches who are not all art education backgrounds, and understand the concepts of theater and theater (dramaturgy, acting techniques, and directing methods, 2) still a negative perception of school theater 3) goodwill and school interpretation of the purpose and benefits of school theater (just perform, practice community or human character building). The school theater is a form of activity that produces beauty with novelty in the work of the show. The work of theater performances in question is the artwork that berdramaturgi as a 'theater process'. Theater pedagogy is interpreted as a theater education, educational process, and theater learning process. A process of changing the attitude and conduct of a person or group of people in an effort to mature human beings through the efforts of teaching and training; processes, ways, and deeds educate with, through / and use the art of theater. To solve the problem of school theater required renewal of the method in running the school theater based on aesthetic thinking and pedagogy.
\end{abstract}

Keywords: Theater School, Aesthetics, Pedagogy

\section{INTRODUCTION}

Saini KM once stated that the Indonesian theater has not really belonged to the community. Indonesian theater is still a big city phenomenon and is only accepted by a small audience (Saini, 2000: 46). Nevertheless, the theater strives to belong to the community in all its forms and developments although most of the audience is generally an intellectual community group. The modern Indonesian theater develops with all its ups and downs and upheavals.

Schools are ideal places to popularize theater right. Theater school can become home to a performing arts theater. Theater school is an organization that 
ISLLAC

Journal of Intensive Studies on Language, Literature, Art, and Culture

Vol. 1 No. 1 September 2017

deliberately established a school with hopes of becoming a developing arena of their students through performing arts theater. In Permendiknas No. 22 year 2006, this self-development activity has been arranged specially. Self-development is not a subject to be cared for by the teacher. Self-development aims to provide opportunities for learners to develop and express themselves according to the needs, talents, and interests of each learner in accordance with school conditions. Facilitated self-development activities and or supervised by counselors, teachers, or educators that can be done in the form of extracurricular activities.

Extracurricular activities are generally considered one-sided, activities that are considered unstructured, free from formal school ties. As a result of this view, of course, the school theater becomes more alienated especially for parents of students whose children are interested in the art of theater. Society is still not fully "literate theater" especially theater schools in East Java is very limited and even especially in Malang does not exist yet. The public does not get much information about theater arts and theater groups enough to make the theater not become alienated.

The first issue that arises when a school theater is held is a resource issue or teacher of theater trainer. Resource issues, especially teachers in the field of theater educator has been a problem for a long time. Sumaryadi (1992) in the journal DIKSI No.1 Th.1 January 1992 has mentioned that the obstacles faced by schools are the scarcity of art teachers in this case theater/drama adviser.

Through Permendikbud No. 62 year 2014 has in fact been elaborated that theater is an optional extracurricular activity that is followed in a planned group and does not inhibit intra- and co-curricular activities, conducted outside of study hours, under the guidance and supervision of educational units, aiming to develop the potential, talents, interests, ability, personality, cooperation, and independence, supported by the availability of coaches. To meet the needs of the coach can be done cooperation with other parties.

The fulfillment of theater coaches who work with outsiders has a positive and negative side. Positive fulfillment of the builder but also negative if one choose a builder who has different views and interpretations of the goals and ideals of the 
ISLLAC

Journal of Intensive Studies on Language, Literature, Art, and Culture

Vol. 1 No. 1 September 2017

theater arts education. There is a view and interpretation that theater in school is also an attempt to form a theater artist. This opinion is not one hundred percent wrong, but it would be a problem if the school theater becomes a medium for experimental artists, if teachers who may also be artists or artists who become teachers more exploit than exploring the ability of art students. The school theater is actually held for what and for whom. School theater should not create new problems between students, parents, teachers, and society.

The second theater problem in schools is that there are negative assumptions about theater activities in general. The theater is considered unstructured, free from formal ties. This assumption also affects the school theater, although in Permendikbud no. 62 year 2014 has been explained that theatrical activities (as extracurricular activities in particular) should be socialized to learners and parents/guardians at the beginning of every school year, need to have systematic activity programs, scheduled, there are achievements, and there are evaluations.

The assumption is the basis of parents guardians of students in schools do not have confidence in the art of theater. Parents assume that theater activity is not useful and this is due to the perception of negative theater activity. Parental distrust of theater is often the main problem in the theater. Students trouble getting permission from parents when going to practice theater (revealed on Dialog Jambore Teater Remaja 2008 in Hall TBJT, August 2nd, 2008).

The third problem is that some people still do not seem to be fully literate in the theater, do not get much information about theater art, how the theater art, especially the school theater and what is actually the function of the theater art for children and society, parents or society in general. This problem has actually long been emerging. Saini KM has stated that the Indonesian theater has not really belonged to the community. Indonesian theater is still a big city phenomenon and is only accepted by a small audience.

In the exciting journey of the famous school theater, in 2007 Garin Nugroho during the staging of the school theater "Si Tomboy and Putri Bungsu" held at the Jakarta Art Building on 13-14 January 2007 also said that should the parents and 
ISLLAC

Journal of Intensive Studies on Language, Literature, Art, and Culture

Vol. 1 No. 1 September 2017

students not viewing the theater as a traditional art. Theater should not be considered ancient and only watched by artists. Garin statement raises the question, whether the theater still remains not in the community?

In 2016 when the Minister of Education and Culture (Anies Baswedan) dispatches Theater Tanah Air to one of the world's theater festivals declaring that theater arts in school should be more echoed again. Theater art has a good effect for children. So far theatrical art has long gone into the realm of school. Activities have been entered through extracurricular activities at all levels of school but interest in the theater arts is still not as expected.

Director of Arts Directorate General of Culture also added, currently the theater actually has a lot of enthusiasts but hampered the socialization aspect to the community. Not all schools have theater activities because art learning such as theater should be done by the parties who understand the theater. This shows that theaters to date have not been fully popularized or in other words people still have not much information about the theater arts, how the theater school and what is actually the function of theater art for children and society, parents or students in general. (Source: http://www.republika.co.id/berita/ Saturday, 16 April 2016,17: 56 WIB)

The fourth problem facing the school theater is the lack of a theater teacher/ theater teacher who ideally has a theater education background. Generally, the theater teacher learns the theater self-taught. Indonesian teachers are cultivators of theater, as Indonesian teachers are considered to understand literature as well as drama. It becomes more complicated when students of extra theater activities do not all understand correctly their purpose of attending the theater at school. This has an impact on the sense of responsibility for what he has done.

Leo Zaeny one of the theater activist in Malang in his website at http: //aromasastra.blogspot.com stated that the art of theater is well known by today's Indonesian teenagers, especially students of junior high and high school. For the theater is one of the means or venues for expressing all ideas, thoughts, interests, and abilities. Through theater, they can express and actualize themselves. Devote his 
ISLLAC

Journal of Intensive Studies on Language, Literature, Art, and Culture

Vol. 1 No. 1 September 2017

abilities and unrivaled. The problem they face is related to the will that is not followed by the sincerity and sense of responsibility, provided there is a simple and perfunctory course. When the will is so great and all their efforts do, finally what happens is the gap between the spirit of practice with the end result. Great responsibility is always directed at the coach or theater teacher who sometimes does not have enough competence that qualified.

School theater looks simple if it is considered simple, but very complicated if the school theater is involved seriously and correctly. On the one hand the school theater is a place for the development of students' interests and talents, but on the other hand, there are demands of school institutions that seek to activate school theater activities with specific goals such as achievement, winning competitions or festivals at local, regional and national levels, until international.

The idea of the theater still has to be maintained even if it is only a school theater. A competitive and prestigious attitude as very reasonable demands. However, if returned to the formal purpose of the theater presented in the school then it will be many questions such as: is it true theater arts as a theater performance formed in the school as part of the effort to develop students' self potential, how interesting the theater art is taught in school, and what kind of theater art should be given at school?

\section{AESTHETICS THEATER SCHOOL}

Aesthetic science is a science that studies all things related to beauty and learns all aspects of what is called beauty. For example: What is the meaning of beautiful?, What is the cause of the beautiful taste?, What causes one thing is beautiful and the other does not?, What causes a sense of feeling that one person feels different from that felt by others?, Is it beautiful lies in the beautiful thing or thing itself or is it just our perception? (Djelantik, 2004: 7).

The Liang Gie (2004: 43) says that there are five conditions that must be met in order to say that something can be said to be beautiful, that is a) unity, totality 
ISLLAC

Journal of Intensive Studies on Language, Literature, Art, and Culture

Vol. 1 No. 1 September 2017

(unity), b) the harmony (barmony), c) symmetry (symmetry), d ) equilibrium (balance), e) the contradiction (contrast).

Meanwhile, artwork by Morris Weitz is an open concept, because in every creation art is often accompanied by renewal. The artwork is dynamic, every artist tends to create something new in his work, no matter how small the update (Nursahid, 2012: 31).

The art of theater performance is essentially inseparable from the aspects of language (dialogue) and body (motion). The works of theater art are filled with symbols of life conveyed through linguistic elements, actors' activities (mimic, gestures and speech), actor, space or place appearance, and non-verbal acoustic sign (sounds and music) in the show to the audience.

Bernhart Clerence (1957: 365) explains the theater as follows.

A composition in prose or verse presenting in dialogue or pantomime a story involving conflict or contrast of character, esp. One intended to be acted on the stage.

The theater is the story of a human life that is arranged to be displayed as a show and played by the actors with characters that can be watched by the public. On the theater, the stage should be more interesting than the reality of life.

Theater as a work of art of performance is basically an expression of public communication, that is an expression of someone in facing the challenge of natural environment and social environment which is manifested in verbal communication and raised with behavior (Maryaeni, 1995: 25).

The art work of theater in Indonesia is a reflection of the culture of the society in the sense of reflection of the reality of life, values, and purpose of life, morality, hopes and ideals of life. Through the art of theater performances, people can get a picture of life about how life really (das sein) and how life should be (das sollen).

The school theater is a form of activity that produces beauty with novelty in the work of his performance. The work of theatrical performances in question is the 91 | 
ISLLAC

Journal of Intensive Studies on Language, Literature, Art, and Culture

Vol. 1 No. 1 September 2017

artwork that berdramaturgi as a 'theater process' which is a place of meeting, collaboration, even 'intercourse' with other branches of art and artists in it to realize a unified whole art, ensemble, and harmonious (Satoto, 2003: 1).

Kernodle (1978: 345-355) explains there are two things that must be understood related to the drama / theater is the structure and texture of the show. The structure is a form of drama during staging. The structure consists of plot, character, and theme (premise). The texture is defined as woven. The texture is analogous to the texture of clothing. To know the texture of clothing, clothing must be touched, felt the difference. The texture is something that must be experienced directly by the observer. The experience comes through the senses, something heard (dialog), something to behold (spectacle), and something that is felt through the visual and aural experience (atmosphere). The texture consists of dialogue, atmosphere, and spectacle. The structure and texture of theater performances are formed from all elements (elements), and braids between elements of the show.

The structure of plot, character, and theme (premise) must be related to life, norm, goodness, evil, evil, and various characters of human character to be displayed. The language and symbols of the playwright (dialogue) through the director's interpretation are implemented in a staging by the actor. The job of directors, actors and other art workers are to communicate concepts, general ideas, patterns, or forms to the audience.

The directors, actors and theater workers seek to find new and contextual idioms and language expressions. A new way of expression with a passion for expressing a growing truth with new languages through a staging texture consisting of dialogue, atmosphere, and spectacle.

Exploration of new idioms is done so that theater art can be accepted acceleratively by the community, especially with the widespread knowledge system and technology and the increase of communication relations in all fields. One of the efforts made is to show theater performances through festivals, competitions, and or theater parade by utilizing technology both in the event of performances and the dissemination of information. 
ISLLAC

Journal of Intensive Studies on Language, Literature, Art, and Culture

Vol. 1 No. 1 September 2017

Festivals activities as a support of the life of theater are held, especially festivals for students. For example, the Directorate of Art and Film Development held an event (FNTR) of the National Youth Theater Festival at Sunan Ambo Building (STSI Bandung). The purpose of these activities is to increase the interest and creativity of adolescents to be more familiar, understand, and appreciate the theater arts. Preparing theater audience in the future so that theater art can live and develop in accordance with the hope of the art world and its support community. Creating a climate of togetherness among teenagers from their respective regions to get to know each other more closely so that it is expected to participate in maintaining the integration of the nation, increasing the appreciation of theater arts among the community both in schools, art studios and families. Organizing the festival is expected to motivate the young generation of Indonesia to continue to be creative, giving the best work to fill the national cultural journey.

In East Java, Indonesia has a Drakolah Award Festival. The event was organized by East Java Provincial Education Department UPT Communication and Information Technology Education followed by the theater of SMA / SMK in East Java, The selection process is done by collecting the results of audiovisual recordings and displayed on youtube. In the early stages selected eight major teams that pass the final stage.

There is also a Historical Festival of East Java held by the Department of Culture and Tourism of East Java. Script writing contest history that results visualized in the form of theatrical performances. One of the winners of the draft is "Dawuhan Dang Atu Pu Sahitya". The manuscript by Rakaihino raises the history of a village in southern Malang that is famous for its prosperity, but, one day the village is in continuous drought. The people complained to the village head named Dang Atu Pu Sahitya. The village chief then went to the royal palace moved from Mataram to meet the King. The king is willing to provide material and energy assistance to build a dam in the village as long as Dang Atu Pu Sahitya introduces the king to his people. The script was able to be visualized by Teater Keong SMAN 7 Malang well in Grand City Surabaya. 
ISLLAC

Journal of Intensive Studies on Language, Literature, Art, and Culture

Vol. 1 No. 1 September 2017

Festival Writing Script and Fragment of Character at Provincial Level is also held by Education Office of East Java. This festival is not only the script writing contest but also the competition to fragmenting script into the form of staging.

\section{PEDAGOGY OF SCHOOL THEATER}

Pedagogy is interpreted as an education that emphasizes the practice, involving educational activities, guiding children. while pedagogic is defined as the science of education is more focused on thinking, reflection on education. A thought of how we guide children, educate children.

Education in the Big Indonesian Dictionary is defined as the process of changing the attitude and behavior of a person or group of people in an effort to mature human beings through the efforts of teaching and training; processes, ways, actions educate. Education refers to a process or event or event. The process is an educational process by the educator and the process of receiving education, or the learning process (in English the equivalent of "learning" is to learn and to study). The concept of education is formed by two processes, educational processes, and learning process.

Referring to the above understanding, theater pedagogy is interpreted as a theater education, educational process, and theater learning process. A process of changing the attitude and conduct of a person or group of people in an effort to mature human beings through the efforts of teaching and training; processes, ways, and educational activities with, through / and using the art of theater.

Theater education is often referred to as a medium to build the character of the nation. Through the theater opened a wide opportunity for artists and all levels of society interested in the arts to build cultural values to stay alive since the beginning of its appearance in the present and the future. Implementation and internalization of cultural values as a concrete manifestation of Indonesia's cultural resilience that is ready to accept the development of the world in a new era, which channeled creativity and productivity through the art of theater. 
ISLLAC

Journal of Intensive Studies on Language, Literature, Art, and Culture

Vol. 1 No. 1 September 2017

Theater art has always been closely linked to education, not only as an artistic creative activity but also of teaching and training activities; processes, ways, and actions to educate to change the attitude and behavior of a person or group of people in an effort to mature humans. Mbiyo Saleh (1967: 213) explains that drama actors/ actresses are people who have a great chance to find themselves. Sihombing (1974: 459) gives the impression that in the United States 'educational theater' is very useful to relax the tension of students and make a significant contribution to the mental health of children. Ki Hadjar Dewantara (1962: 310) also explained that the teaching of the drama is very supportive of teaching in knowledge and intelligence, such as language teaching, literature, talking to. new insights, rhythm exercises, singing, adjusting words with thoughts, feelings, will and energy, teaching courtesy, and so on.

Theater education in schools is implemented based on Government Regulation No. 19/2005 on National Education Standards. Theater education is a cultural-based art education that covers all aspects of life. Theatrical education is given in schools because of the uniqueness, meaningfulness, and usefulness of developmental needs in providing an aesthetic experience in the form of expressive / creative activities and appreciation through the approach: "learning by art," "learning through art" and "learning about art". The aesthetic experience is meant to increase the sensitivity, the ability to express and the ability to appreciate beauty and harmony, both in individual life and in community life so as to create harmonious togetherness.

Theater art is a self-development activity that has been specially arranged in Permendiknas no. 22 of 2006. Self-development is not a subject that should be taught by teachers. Self-development aims to provide opportunities for learners to develop and express themselves according to the needs, talents, and interests of each learner in accordance with school conditions. Self-development activities are facilitated and / or guided by counselors, teachers, or educational personnel that can be done in the form of extracurricular activities. 
ISLLAC

Journal of Intensive Studies on Language, Literature, Art, and Culture

Vol. 1 No. 1 September 2017

\section{CONCLUSION}

The phenomenon of school theater can be classified into several problems, among others: 1) the resources of teachers and coaches, not all art education background, understanding the theater and theater concept (dramaturgy, acting technique, and directing method, 2) the negative perceptions of school theater 3 ) goodwill and school interpretation of the purpose and benefits of school theater (just perform, practice community or human character development).

These issues are the classic issues that always arise when questioning the school theater, and should be solved by looking at the aesthetic and pedagogical essence of school theater. The school theater though only as an extracurricular activity and underestimated but meets the aesthetic standards of art, should not be questioned and should be developed.

When the school theater has a clear purpose, it is held for whom and for what, and the school theater is not just an experimental media "artist", not just for a group of students (exclusive group), does not create new problems between students, parents and teachers, the school theater is able to build the culprit, the people, the audience who gladly watch, then the school theater should be maintained and developed.

The school theater not only creates future theater actors, but also the audience who understand how to enjoy the theater and how to be a savvy theater audience. From the school, theater should grow the performers and theater audiences in the community.

The higher theater competition, especially the school theater, it becomes an interesting cultural event to be observed. Halim HD as a theater observer who looked at the aesthetics of Indonesian theater during the discussion titled "Rereading Aesthetics of Our Theater" held at Teater Kecil, Taman Ismail Marzuki, Jakarta, revealed the aesthetic weaknesses of Indonesian theater today. For him, the general phenomenon in Indonesian theater lately is a language that seems bright and clear, but it does not make the problem becomes clear and lose imaginative space. 
ISLLAC

Journal of Intensive Studies on Language, Literature, Art, and Culture

Vol. 1 No. 1 September 2017

Language is often no longer because the mouth is only a loud speaker. (Sinar Harapan, June 14, 2014).

If the language of the theater is said to be as though bright and plain, but it does not make the problem clear and lose imaginative space, it should be suspected that there are problems to be solved or sought the way out. It is necessary a new method in running theater, especially the school theater based on aesthetic and pedagogical thoughts.

\section{REFERENCES}

Clarence, B. (1957). The American College Dictionary. New York: Harper \& Brothers Publisher.

Dahana, R. P. (2001). Ideologi Politik dan Teater Modern Indonesia. $\quad$ Magelang. Yayasan Indonesiatera.

Dewantara, Ki H. (1962). Karya Ki Hadjar Dewantara. Yogyakarta: Taman Siswa. VII, Agustus 1974.

Djelantik, AA. (2004). Estetika Sebuah Pengantar. Jogjakarta . MSPI.

Kernodle, G. \& Portia, K.(1978). Invitation to the Theatre. New York: Harcourt Brace Javanovich.

Langer, S. K. (2006). Problematika Seni. Bandung. STSI Bandung

Liang Gie, The. (2004). Filsafat Seni.Yogyakarta: Penerbit Pusat Belajar Ilmu Berguna.

Malna, A. (2010). Perjalanan Teater Kedua: Antologi Tubub dan Kata. Jogjakarta: iCAN (Indonesia Contemporary Art Network)

Marco, De M, (1993). The Semiotics of Performance, Translated Aine O'Heady, Bloomington and Indianapolis: Indiana University Press

Maryaeni.(1995). Buku II Teater. Malang: Proyek IKIP Malang.

Maryaeni, Suherjanto, I., \& Kamal, M. (2013). Pengembangan Materi Ajar Drama/Teater Berbasis Pendidikan Karakter dan Kearifan Lokal di Lembaga Pendidikan (SD,SMP, SMA) di Kabupaten Malang. Laporan Penelitian. LP2M UM. Malang 
ISLLAC

Journal of Intensive Studies on Language, Literature, Art, and Culture

Vol. 1 No. 1 September 2017

Nazir, M. (2005). Metode Penelitian, Ghalia Indonesia. Jakarta

Oemaryati, B S.(1971). Bentuk Lakon dalam Sastra Indonesia. Jakarta: Gunung Agung

Ommaney, K. A. (1939). The Stage and the School. New York: Harper \& Brothers Publisher.

Rendra, WS. (1976). Bermain Drama. Jakarta: Pustaka Jaya.

Sahid, N. (2010). Tema Dan Penokohan Drama Orde Tabung Teater Gandrik: Kajian Sosiologi Seni dalam Kajian Linguistik dan Sastra Vol.2 No.2 December, 2010

Saini KM. 2000, 'Teater Indonesia Sebuah Perjalanan dalam Multikulturalisme`. Interkulturalisme (dalam) Teater. Ed. Nur Sahid. Yayasan untuk Indonesia

Saleh, M. ( 1967). Sandiwara dalam Pendidikan, Jakarta: Gunung Agung

Sihornbing, W. (1974). "Masalah Educational Theatre" Budaya Jaya No. 75

Simatupang. S. R (2014)Membahas Peta Estetika Teater Indonesia diunduh dari http://sinarharapan.co/news/ March 19, 2015

Soedarso, SP. (1990). Tinjanan Seni: Sebuah Pengantar untuk Apresiasi Seni. Jogjakarta: Suku Dayar Sana.

Soemanto, B. (2001). Jagat Teater. Jogjakarta: Media Pressindo.

Sutrisno, M. (2006). Oase Estetis. Kanisius. Jakarta

Sumardjo, J. (1992). Perkembangan Teater Modern dan Sastra Drama Indonesia . Bandung: PT Citra Aditya Bakti.

Sumarjo, J. (2000). Filsafat Seni. Bandung: ITB.

Trotsky, L.(1998). Seni dan Politik dalam Seni, Politik dan Pemberontakan. Jakarta: Bentang Budaya.

Wellek \& Warren. (1995). Teori Kesusastraan. Jakarta: PT Gramedia Pustaka Utama.

Zaeny. L. (2014). Teater Remaja dan Persoalannya diunduh dari http: L/aromasastra.blogspot.com March 19, 2015 